\title{
Spreading the Word: Evangelism and the Posturing of Evil
}

\author{
George Catsi
}

\begin{abstract}
Visions of a fundamentalist Christian America are pumped into millions of American homes through Christian television and radio stations. Plus the voices of individual preachers, pastors and healers push out via TV syndication, podcasts, vodcasts and niche websites to a vast global audience. These mass communication mediums have allowed the dissemination of points of view of congregations and individual ministers, from mainstream to isolated or splinter groups, to penetrate a vaster audience and search out like minded people way beyond the limits of their hometown.

Indicators of dislocation, disenfranchisement, rapid globalisation and unemployment provide fertile grounds for the rhetorical and morally simplistic language conveyed through vast and organised mediums to influence and convert. This language of defining evil, as part of a moral absolutism, has permeated the mainstream to counter the belief that the conversation has for too many decades been dominated by the amoralists claim to the meaningless of good and evil. This moral war has defined and dominated the recent resurgence on the narrative of Evil.
\end{abstract}

Fundamentalist organisations, such as the Westboro Baptist Church, define and express their perception on the nature of evil: www.godhatesfags.com and www.godhatestheworld.com and as such have been themselves defined as evil by the very church they state they represent. Pro-lifers kill Christian abortionists whilst preachers incite like Reverend Jerry Falwell's revelation on September13, 2001, that God had opened up the nation to devastation because of the unholy workings of, among other constituencies, "the pagans, and the abortionists, and the feminists, and the gays and the lesbians".

This paper looks at examples of the Evangelism of evil plus the role of US Christian Fundamentalists in pushing to define a universal transcendent definition of evil and how they disseminate an absolutist point of view.

Key Words:

Evangelism, Westboro, fundamentalism, Christian, Falwell, evil, moral, absolutism, fascist, crusade. 


\section{Know Thine Enemy}

'Evil is a Value Judgement', says Dr Michael Stone who created the Depravity Scale but I argue that Christian fundamentalists believe the judgement has already been made for us. ${ }^{1}$ For them the Bible provides all the answers to all the questions on what is right and what is wrong. This language of defining evil, as part of a moral absolutism, has permeated the mainstream to counter the belief that the conversation has for too many decades been dominated by the amoralists claim to the meaningless of good and evil.

Some have come to say that because of this moral absolutism Christian Fundamentalists are evil or capable of evil, if evil is seen as a binary universe of inclusion and exclusion.

Whilst a comment about, or to a Christian Fundamentalist, elicits a response from most that is opinionated and positioned, a deeper understanding seems to be lacking from most media, science and public commentary. A posturing from both sides has manifested into what appears on the surface as 'us and them' positioning. Who is a fundamentalist and where their worldview comes from is valuable to understand and clarify and what makes these groups attractive, allowing the fundamentalist to convert and keep ever growing numbers. Indicators of dislocation, disenfranchisement, rapid globalisation and unemployment provide fertile grounds for the rhetorical and morally simplistic language conveyed through vast and organised mediums to influence and convert.

People who come to join churches come to search for meaning. There are many psychological theories that talk about meaning systems and this can be surmised as a group of beliefs or theories that include both a world theory and a self theory and these meaning systems aid individuals in setting goals, regulating behaviour and experiences, planning activities, and sensing direction and purpose of life, and then to make self-evaluations in relation to all these experiences. For a religious person the search for meaning and significance involves the sacred. ${ }^{2}$

For academics, psychologists and social scientists, identifying what is sacred is what keeps them employed, however this is unnecessarily pedantic to fundamentalists. The sacred is quite simply, 'that what has been ordained by the Divine Being through the sacred text'. ${ }^{3}$ For them the Bible alone is the direct and literal revelation of God, and that it is therefore the totally sufficient source of meaning and purpose to life. Islam makes similar 
assertions about the centrality of the Quran, however for fundamentalists of any faith, in the library of life there aren't 2 books.

We need to try and have an understanding that for many, religious fundamentalism provides a unifying philosophy of life within which personal meaning and purpose are embedded. In short, religion can be a total way of life. Religion is a systemised and complex system that requires an authoritative base capable of subordinating to itself all other elements of human experience. Subordinating all else to a supreme authoritative text is an important defining characteristic of fundamentalism. Fundamentalism's psychological staying power is its ability to create a unifying philosophical framework that meets personal needs for meaning and provides coherence to an existence that might otherwise seem fragmented. It is not therefore surprising that the most successful religions, in terms of both growth and maintenance of membership, are those with absolute, unwavering strict, and enforced normative standards for behaviour. ${ }^{4}$ They provide moral certainty and stability, therefore contributing to a sense of coherence in an otherwise chaotic world. ${ }^{5}$

A key point that people attack Christian fundamentalists for is their interpretation of their sacred text, the Bible. However Hood ascertains that we must look at the text they hold dear and see how it moulds the beliefs and the characters of those who adhere to its words. The centrality of the text is what permits you to understand fundamentalism from within:

You must take seriously what fundamentalists take as axiomatic: that there exists an objective truth - revealed, recorded, and adequately preserved - illuminating intent that can be grasped and valued as the foundation for understanding all of life. ${ }^{6}$

Hood, Hill and Williamson tried to explain this as an intratextual model - the reader must go into the text and allow the text to speak for itself but the voice must come only from within the text. This can be described as a drawing of an unbroken circle and within it sits the Sacred Text and Absolute Truths plus the Principle of Intratexuality. Ones whole world and way of being in the world is defined by what is in the circle. The Sacred text, in the case of Christianity, the Bible, reveals to the reader the Absolute Truths on the whys and hows of life. Everything outside the circle is seen as a peripheral belief that is interpreted and responded to only in relation to what is in the circle. ${ }^{7}$ 
Critics or believers are kept at distance. All who refuse to embrace the text as the sole authority are perceived as a threat to the security and purity of the worldview.

Christian Fundamentalists are not necessarily closed-minded but rather seek to search the sacred text for all knowledge. It is their overarching guide and the justification for all thought and action. They support other forms of knowledge, including science and historic criticism - however whatever peripheral beliefs emerge, they must be ultimately judged and seen as harmonious with what is in the bold circle. ${ }^{8}$ Evolution is not $\mathrm{OK}$ as it questions the sacred belief of creationism, however the world being round and not flat is $\mathrm{OK}$ as there is no fixed view in the Bible on this.

This closed circle indicates an exclusion of other interpretive factors but also that absolute truths derived from the process are themselves protected from outside influences and are not subject to criticism. ${ }^{9}$

To quote, the famous Christian fundamentalist, D. L. Moody, "I have one rule about books, I don't read any book, unless it helps me understand THE book"10

More liberal churches are seen as having a circle of a dotted line, an inter-textual model. Peripheral beliefs can flow into the circle and develop what happens to the interpretation of the sacred text. ${ }^{11}$ As an example, evolution is seen as more of Gods universe being revealed though science. There is less literal interpretation of the biblical verse. Fundamentalists can find liberal churches to be an equal enemy as the non-believers for their nonadherence to their perceived absolute truths and fostering uncertainty.

\section{Growth of Fundamentalism Churches in US}

Recent Gallup surveys cited by Hedges suggest 70 million evangelicals in US (25\% pop) attending more than 200,000 evangelical churches. Polls indicate around $40 \%$ believe the Bible is the actual word of God. A 2004 study by political scientist John Green identifies approximately $12 \%$ of this group as traditional evangelicals or what the media has labelled the 'religious right'. ${ }^{12}$

To protect the sanctity of the word they have developed closed systems of information where their followers can learn from the start of school through to university in a system that filters all learning through the biblical paradigm. ${ }^{13}$ Tens of millions of Americans view Christian Broadcasters for their news, health, entertainment and devotional programs. 
Whilst they shun modernism for its liberal thought they understand the power of the media and the medium to convey their message.

\section{The Crusade - You're either with us or you are against us}

$17^{\text {th }}$ century theologian Blaise Pascall said, "Men never do evil so completely and so cheerfully as when they do it from religious conviction" ${ }^{14}$

The posturing of certain fundamentalist evangelicals has been provocative and divisive from both outside and inside the Christian community:

- Pastor Danny Nalliah from the unfortunately named Catch the Fire Ministries in Victoria, Australia who after the recent bush fires that killed 200 people said that, "it was Gods punishment for the Victorian Parliament passing pro-abortion laws". ${ }^{15}$

- Pastor Pat Robertson, US evangelist, blamed the 7.3 magnitude earthquake in Haiti on the Haitians' "pact with the devil" two centuries ago while seeking liberation from the French. ${ }^{16}$

- Reverend Jerry Falwell's revelation on September 13, 2001, "that God had opened up the nation to devastation because of the unholy workings of, among other constituencies, "the pagans, and the abortionists, and the feminists, and the gays and the lesbians". ${ }^{17}$

- Pastor Rod Parsley of the World Harvest Church with a 12,000member congregation peppers the language of war and violence into his sermons. Words such as; Islam intends to use violence to conquer the world; Christian America has been mandated by God to do battle and defeat all demons. The church that claims to hold the cause of right, yet condemns confrontation is little more than a social club." ${ }^{18}$

- Westboro Baptist Church, define and express their perception on the nature of evil via their websites: www.godhatesfags.com , www.godhatestheworld.com (plus others) and their hate for the US government for allowing homosexuality to exist and manifesting this by picketing the funerals of US soldiers. As such, the very church that they state they represent has turned them on. ${ }^{19,20}$

Pastor Russell Johnson, from Ohio, talks of an embattled Christian America and calls for a war of values and morals, of decency and goodness, 
pitted against forces of darkness and evil, has enveloped the country and he issues a strident call to arms. He likens America's predicament to that of Nazi Germany. He accuses America of leading "Neville Chamberlain lives" of appeasement. If Christians do not act they will be next. They will be hauled off in freight cars like the Jews and murdered.

Hedges states, that this Rhetoric creates an atmosphere of being under siege. It imparts the glow of comradeship, the feeling that although outside these walls is a dangerous, hostile world; here we are all brothers and sisters. It is clear to whom we bear a moral obligation: to fellow Christians. This creates a world where there are only 2 types of people. There are godly men and women who advance Christian values, and there are non-believers many of them liberal Christians - who peddle the filth and evil of secular humanism. ${ }^{21}$

This has to a certain extent has manifested into what Al Gore notes, that the single most surprising element in the American conversation is the prominence and the intensity of constant fear, with persistent confusion about the sources of that fear. Americans are now have difficulty distinguishing between illusionary threats and legitimate ones. ${ }^{22}$

The object of hatred has shifted from the likes of communists to individuals and institutions promoting secular humanism preferring now to demonise gays, liberals, immigrants and Moslems.

\section{Evil outside self must be destroyed}

This exclusive community fosters rigidity, conformity and intolerance where segments of non-Christian community are disqualified from moral or ethical considerations. Fundamentalist followers live in a binary universe. Therefore one can conclude that if they seek to destroy nonbelievers to create a Christian America, then nonbelievers must be seeking to destroy them. When evil is always external, then one can surmise that moral purification would entail the eradication of others.

The rhetoric of depersonalisation creates a frightening moral fragmentation, an ability to act with compassion and justice to those within the closed, Christian circle and yet allow others outside the circle to be abused, silenced and stripped of their rights. Do they not mean what they say when they talk about the persecution of homosexuals or nonbelievers or that they will execute abortion providers? The later has been proved time and again with the recent slaying of the prominent late-term US abortion provider George Tiller who was shot dead in a church where he was serving. ${ }^{23}$ 
There is culture of rage and despair across America. Job losses sending people to the poorly paid service sector; abuse, neglect and abandonment by government; a crisis of identity as the US's global standing seems under threat of collapse; a long protracted war. ${ }^{24}$ These are good figures for religion. What's bad for politics, what's bad for people is potentially good for religion.

Fundamentalist churches offer certainty and family like most churches however there is the prevailing Fundamentalist message that creates a difference, for when the Rapture comes and the Lord returns all those forces and people who have conspired against you will be destroyed. It will be the ultimate final solution.

\section{Notes}

${ }^{1}$ J Arehart-Treichel, 'Psychiatrist Helps Court Define 'Evil Behaviour', Psychiatric News vol.36/no.12 (2001) Page 9,

${ }^{2}$ R Hood, P Hill, and P Williamson, 'The Psychology of Religious

Fundamentalism', 1st edn, New York, Guilford Press, 2005, p.16

${ }^{3}$ ibid p. 15

${ }^{4}$ L Iannaccone, 'Why Strict Churches are Strong', The American Journal of Sociology, vol. 99/no. 5, (1994), pp. 1180-1211.

${ }^{5}$ R Hood, P Hill, and P Williamson, op. cit., p. 15

${ }^{6}$ ibid., p. 21

${ }^{7}$ ibid., p. 22

8 ibid., p. 25

${ }^{9}$ ibid., p. 27

${ }^{10} \mathrm{R}$ Hofstadter, 'Anti-Intellectualism in American Life', 1st edn,

New York, Knopf, 1963, p.108

${ }^{11}$ Hood, op. cit., p. 27

${ }^{12} \mathrm{C}$ Hedges, 'American Fascists: The Christian Right and the War on America', Free

Press paperback edn, New York, Free Press, (2008), p18 -19

13 ibid, cited p56

$14 \quad$ Blaise Pascall, The Quotations Page

http://www.quotationspage.com/quote/27619.html viewed 16/02/2010

${ }^{15}$ Feneley, R. 'Pastor's Abortion Dream Inflames Bushfire Tragedy', Sydney Morning Herald,

Feb 11,2009, http://www.smh.com.au/national/pastors-abortion-dreaminflames-bushfire-tragedy-20090210-832f.html 
16

'Pat Robertson Blames Haiti Quake on 'Pact with the Devil ',

Chicago Tribune

Newsblog, (2010),

http://newsblogs.chicagotribune.com/religion theseeker/2010/01/pat-

robertson-blames-haiti-quake-on-pact-with-devil.html viewed 16/02/2010

17

Pat Robertson, SourceWatch, The Centre for Media and Democracy,

$<$ http://www.sourcewatch.org/index.php?title=Pat Robertson $>$, viewed $16 / 02 / 2010$

${ }^{18}$ Hedges, op. cit., p. 158, 159,163

${ }^{19}$ Brower, D. C., and Hess, A., 'Making Sense of 'God Hates Fags' and 'Thank God for 9/11':

A Thematic Analysis of Milbloggers' Responses to Reverend Fred Phelps and the Westboro Baptist Church', Western Journal of Communication, vol. 71/no. 1, (2007), pp. 69-90.

${ }^{20}$ God Hates Fags, Westboro Baptist Church http://www.godhatesfags.com and www.godhatestheworld.com viewed 09/07/2009

${ }^{21}$ Hedges, op. cit., p. 148-150

${ }^{22}$ Gore, A., 'The Assault on Reason', Penguin Press, New York, (2007)

23 'Anti-Abortion Leaders Fear Backlash After Shooting', Sydney

Morning Herald, Associated Press 02/06/2009,

http://www.smh.com.au/world/abortion-doctor-shot-dead-at-his-church20090601-brvy.html

${ }^{24}$ Hedges, op. cit., p. 42,43

\section{Bibliography}

Arehart-Treichel, J., 'Psychiatrist Helps Court Define 'Evil Behaviour', Psychiatric News vol.36/no.12 (2001)

Brower, D. C., and Hess, A., 'Making Sense of 'God Hates Fags' and 'Thank God for 9/11': A Thematic Analysis of Milbloggers' Responses to Reverend Fred Phelps and the Westboro Baptist Church', Western Journal of Communication, vol. 71/no. 1, (2007), pp. 69-90.

Feneley, R. 'Pastor's Abortion Dream Inflames Bushfire Tragedy', Sydney Morning Herald, Feb 11,2009, http://www.smh.com.au/national/pastorsabortion-dream-inflames-bushfire-tragedy-20090210-832f.html 
God Hates Fags, Westboro Baptist Church http://www.godhatesfags.com and www.godhatestheworld.com viewed 09/07/2009

Gore, A., 'The Assault on Reason', Penguin Press, New York, (2007)

Hedges, C., 'American Fascists: The Christian Right and the War on America', Free Press paperback edn, New York, Free Press, (2008)

Hofstadter, R., 'Anti-Intellectualism in American Life', 1st edn, New York, Knopf, 1963, p.108

Hood, R., Hill, P. and Williamson, P., 'The Psychology of Religious Fundamentalism', 1st edn, New York, Guilford Press, 2005, p.16

Iannaccone, L., 'Why Strict Churches are Strong', The American Journal of Sociology, vol. 99/no. 5, (1994), pp. 1180-1211

'Anti-Abortion Leaders Fear Backlash After Shooting', Sydney Morning Herald, Associated Press 02/06/2009, http://www.smh.com.au/world/abortion-doctor-shot-dead-at-his-church20090601-brvy.html

Blaise Pascall, The Quotations Page viewed 16/02/2010 http://www.quotationspage.com/quote/27619.html

Pat Robertson, SourceWatch, The Centre for Media and Democracy, $\overline{<\mathrm{htt}}$ ://www.sourcewatch.org/index.php?title=Pat Robertson $>$, viewed $16 / 02 / 2010$

'Pat Robertson Blames Haiti Quake on 'Pact with the Devil ', Chicago Tribune Newsblog, (2010),

http://newsblogs.chicagotribune.com/religion theseeker/2010/01/patrobertson-blames-haiti-quake-on-pact-with-devil.html viewed 16/02/2010

George Catsi is completing a Doctorate of Creative Arts at the University of Technology Sydney, Australia. His research is exploring the tools and techniques of persuasion focusing on the US Christian Right. George is developing a concurrent creative project that explores the research by creating a satirical evangelical church. 